Table 1. The numbers represent the dilutions which cause complete inhibition of Myco. smegmatis for 6 days and Myco. tuberculosis for $\mathbf{4 2}$ days

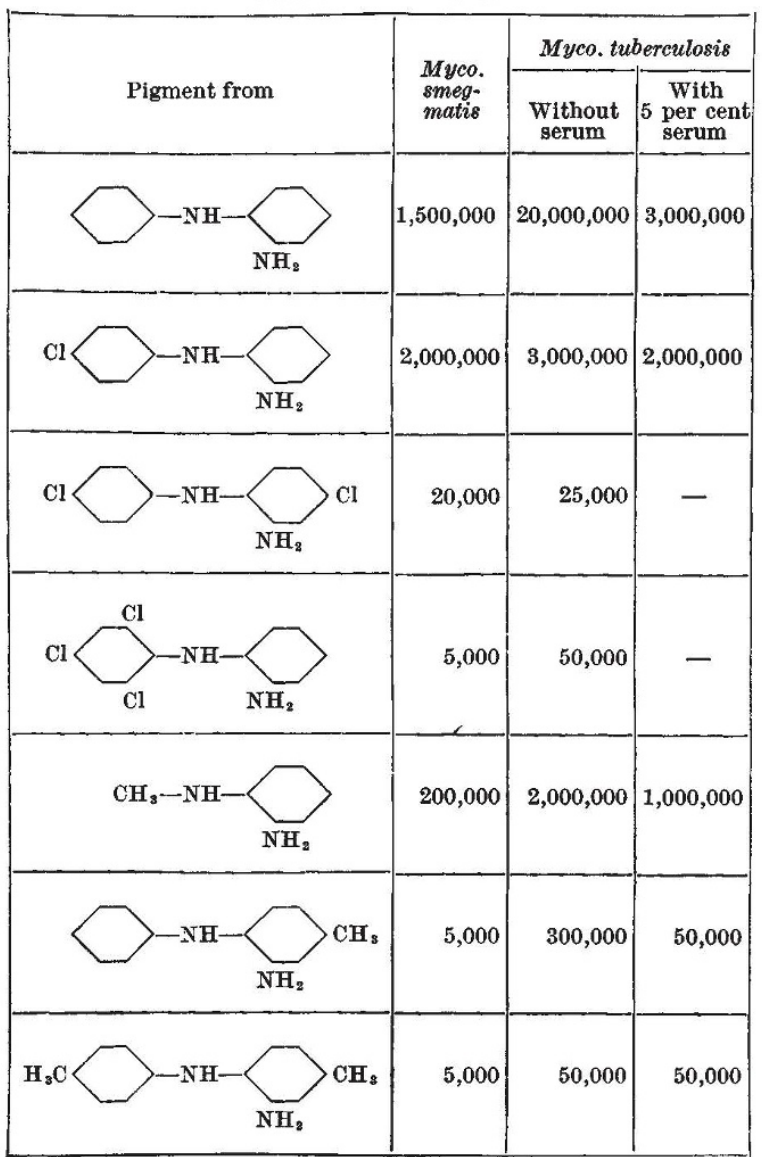

showed that it had no inhibitory effect on this organism at $1 / 5,000$, but that it was decolorized by the bacteria. Subcutaneous or intramuscular injection of the hydrochloride of (I) in guinea pigs in doses of 5-35 mgm. produced severe local toxicity, and this mode of administration could not be continued. Intravenous injection in rabbits proved rapidly fatal. When 2-aminodiphenylamine hydrochloride is oxidized by ferric chloride in the presence of human serum, a very deep red pigment is formed which does not separate. Menkin ${ }^{10,11}$ has successfully administered ferric chloride intravenously. In view of this and in the hope that the toxic effect might be reduced if the pigment were produced in the blood stream,

Table 2. Antibacterial activity of the pigment (I) from.2-aminodiphenylamine. The figures given in the third and fourth columns represent the dilutions which cause complete inhibition of growth

\begin{tabular}{|c|c|c|c|c|c|c|}
\hline \multicolumn{4}{|c|}{ Organism } & $\begin{array}{l}\text { Period } \\
\text { of } \\
\text { growth } \\
\text { (days) }\end{array}$ & $\begin{array}{c}\text { Inhibitory } \\
\text { dilution } \\
\text { in } \\
\text { broth }\end{array}$ & $\begin{array}{c}\text { Inhibitory } \\
\text { dilution } \\
\text { in broth } \\
+5 \text { per cent } \\
\text { human } \\
\text { serum }\end{array}$ \\
\hline $\begin{array}{l}\text { Myco. tuberculo } \\
\text { Myco. smegmat } \\
\text { Corynebacterium } \\
\text { Staph. aureus } \\
\text { Strep. foecalis } \\
\text { Strep. pyogenes } \\
\text { Strep. viridans } \\
\text { Vibrio } 10 \\
\text { B. typhosus } \\
\text { Bact. coli }\end{array}$ & $\begin{array}{l}\text { iaphth } \\
\therefore \\
\therefore \\
\therefore \\
\therefore \\
\therefore\end{array}$ & 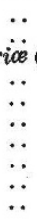 & $\begin{array}{c}t i s) \\
\cdots \\
\because \\
\because \\
\because \\
\because \\
\cdots\end{array}$ & $\begin{array}{r}42 \\
6 \\
3 \\
3 \\
3 \\
3 \\
3 \\
3 \\
3 \\
3\end{array}$ & $\begin{array}{r}20,000,000 \\
1,500,000 \\
7,500,000 \\
200,000 \\
100,000 \\
200,000 \\
80,000 \\
10,000 \\
80,000 \\
<5,000\end{array}$ & $\begin{array}{r}3,000,000 \\
1,500,000 \\
60,000 \\
<60,000 \\
10,000 \\
<60,000 \\
20,000 \\
10,000 \\
5,000 \\
\end{array}$ \\
\hline
\end{tabular}

rabbits were injected intravenously with 2 -amino. diphenylamine (15 mgm., 2 c.c.), followed by ferric chloride (15 mgm., 6 c.c.). The rabbits died, however, after an average total quantity of $100 \mathrm{mgm}$. of 2-aminodiphenylamine had been given over a period of fourteen days, a quantity comparable to the amount of (I) which had already proved lethal intravenously.

While it is clear that the high toxicity of (I) for animals renders it unsuitable for therapeutic use, it may be possible to reduce the toxicity of this structure without destroying its antibacterial power. This might be achieved by increasing the solubility of the pigments by including an $\mathrm{OH}, \mathrm{COOH}$ or similar group in (I), or alternatively by synthesizing pigments of lower molecular weight. The pigment produced from $\mathrm{N}$-methyl-o-phenylene diamine (Table I) has very high activity against the tubercle bacillus, and its toxicity to animals should be lower than that of (I). These alternatives are being investigated.

These synthetic pigments are of added interest because of their relation to the bacterial pigments, pyocyanine, chlororaphin and iodinin, all of which are phenazine derivatives. Also Iland has reported recently on the high antitubercular activity in vitro of $\mathrm{N}$-oxides of phenazine ${ }^{12}$.

This investigation is being conducted and financed by the Medical Research Council of Ireland, to which grateful acknowledgment is made. The strains of Myco. tuberculosis used in these experiments were provided by the Trudeau Foundation. Our thanks are due to Mrs. E. Philbin for assistance.

${ }^{1}$ Barry, V. C., O'Rourke, L., and Twomey, D., Nature, 160, 800 (1947). ${ }^{2}$ Fischer, O., and Seeder, L., Berichte, 22, 3798 (1889).

${ }^{3}$ Schöpff, M., Berichte, 23, 1839 (1890).

${ }^{4}$ Ernst, O., Berichte, 28, 3426 (1890).

${ }^{5}$ Kehrmann, F., and Messinger, J., J. Präkt. Chem., 46, 568 (1892).

${ }^{6}$ Fischer, O., and Heiler, O., Berichte, 26, 378 (1893).

'Kehrmann, F., Berichte, 28, 1709 (1895).

${ }^{8}$ Fischer, O., and Dischinger, A., Berichte, 29, 1602 (1896),

- Kehrmann, F., Berichte, 22, 1983 (1889).

${ }^{10}$ Menkin, V., J. Exp. Med., 60, 463 (1934).

${ }^{11}$ Menkin, V., Amer. Rev. Tub., 35, 134 (1937)

12 nand, C. N., Nature, 161, 1010 (1948).

\section{TENTH INTERNATIONAL LIMNOLOGICAL CONGRESS, ZURICH}

$T$

HE International Association for Theoretical and Applied Limnology, the object of which is to provide a common meeting ground for those interested in the biology and utilization of fresh waters, achieves its purpose by means of congresses which are ordin. arily held every two years and the proceedings of which are afterwards published. Between successive congresses, matters requiring attention are dealt with by the president, the secretary and a small executive committee, while reference can also be made to the members of an international committee upon which each participating country has one or more representatives. The last congress met in Sweden in 1939 and, apart from all other considerations, that held this year in Switzerland will be memorable for the renewal of old friendships and the opening up of new avenues of scientific intercourse. It was attended by about a hundred and sixty individuals representing twenty-one different nations, and the British group was one of the largest. 
The opening session on the first evening, at which formal business tempered by interludes from a firstclass string quartette was transacted, was held in the spacious Zurich Congress House. On this occasion Naumann Medals, which are awarded for distinguished services to limnology, were presented to the American Society for Limnology and Oceanography and to the Freshwater Biological Association of the British Empire. The evening concluded with a supper, at which the Swiss organising committee were our hosts, and which served to a remarkable degree to establish contact between the different nationalities present.

The scientific work of the Congress was largely concentrated into the mornings of August 19 and 20 and the morning and afternoon of August 22. On each occasion there were simultaneous sessions concerned with general limnology and with freshwater fisheries, while on August 22 there were other sessions devoted to water utilization and water sanitation. The many short papers read at these various sessions, a considerable number contributed by the British members, covered a wide range of topics. The ecology of river-populations and self-purification in rivers, phytoplankton problems and the fungal parasites of the phytoplankton, the ecology and distribution of diverse freshwater Invertebrata, the regional limnology of Switzerland, seasonal changes at the mudsurface and detritus-drifts in lakes, fish-culture and sex in fish, the chemistry of sewage disposal waters, and the biology of filters were among the numerous subjects discussed. There were also several lectures on major topics. Of quite special interest, in view of its relation to the many lakes visited on the excursions, was the symposium on the recent development and present biological condition of the lakes bordering the Alps, in which Profs. Jaag (Zurich), Baldi (Pallanza), and Ruttner (Lunz) took part. On August 20 Profs. Steinmann (Aarau) and Willer (Hamburg) dealt with the taxonomic problems afforded by the genus Coregonus, discourses which proved of great interest even to those not directly concerned with fisheries, while on August 22 F. W. Mohlman (Chicago) gave an account of recent developments in industrial waste disposal. On this, the last evening in Zurich, the Town Council entertained the members of the Congress to dinner.

The excursions, which were designed to illustrate much of the matter that had been discussed during the scientific sessions, were excellently organised and were marked by the lavish hospitality that accompanied them. The afternoons of August 19 and 20 were devoted respectively to a visit to the Cantonal Fish Breeding Station at Stäfa, and to a trip by motor coach to various small lakes in the vicinity of Zurich. The whole of August 21 was taken up by a visit to the falls of the Rhine at Schaffhausen and to the "Untersee" (Lake of Constance), while on August 24 most of the members visited the laboratory on the Jungfraujoch. Both these full-day excursions were favoured by good weather and must have left a deep impression on the participants. On August 23 we travelled from Zurich to Interlaken via Lucerme and the Brünig Pass, making a stay of several hours at Kastanienbaum to visit the small but well-equipped hydrobiological station, originally founded by $\mathrm{H}$. Bachmann and now maintained by the Natural History Society of Lucerne. The latter very generously entertained us to lunch.

The concluding session on August 25 was held at Montreux. Dr. Gunnar Alm (Drottningholm, Sweden) was re-elected president of the Association, while Dr. Rohde (Uppsala) was elected secretary in succession to Prof. Lenz (Plön), who had filled this office since the foundation of the Congress in 1922. It was decided that the next congress should meet in Belgium in 1950, and the ensuing one in Britain in 1952 .

It is impossible to say too much in praise of the general organisation that rendered the Congress so unqualified a success, or in acknowledgment of the generosity that made so much available to the members for so small a financial outlay. Among the many Swiss men of science who were concerned, special mention should be made of the head of the Organising Committee, Dr. Huber-Pestalozzi, and of his associates Prof. O. Jaag and Dr. U. Corti, while Mrs. Minder, though never to the front, was a help and guide to all participants.

F. E. Fritsch

\section{SEMICONDUCTORS AND THEIR APPLICATIONS}

$\prod_{t h \theta}$

HE summer meeting of the Manchester and District Branch of the Institute of Physics at the University of Manchester took the form of a two-day conference on semiconductors and their applications. The chairman of the branch, Prof. E. G. Cox (Leeds), presided.

The purpose of the conference was to bring together those working on the fundamental physics of semiconductors, those making such substances commercially, and those applying them in various branches of science and engineering.

The opening session was concerned with the fundamental theory of the behaviour of electrons in semiconductors. Dr. J. W. Mitchell, of the University of Bristol, began by distinguishing between conduction in metals, in semiconductors and in insulators. In semiconductors, conductivity increases with temperature and with the amount of impurity present. The characteristic relation between conductivity, $\sigma$, and absolute temperature, $T$, is

$$
\sigma=a e^{-E / k T}
$$

where $E$ is an activation energy. Dr. Mitchell then developed most concisely the wave-mechanical concepts of electrons in ionic crystals and the conditions obtaining in periodic lattices which lead to the splitting of allowed energy-levels for the electrons into large numbers of closely spaced levels, that is, bands. The effects of the presence of defects and impurities in such a lattice were considered, and the distinctions between excess ( $n$-type) and defect ( $p$-type) semiconductors made clear. In the first type, the carriers of charge are electrons, and in the second they are 'positive holes'. For example, sodium chloride when heated to $600^{\circ} \mathrm{C}$. in an atmosphere of sodium vapour turns orange, due to the formation of ' $F$-centres', and at $300^{\circ} \mathrm{C}$. under the influence of an electric field the coloration moves towards the anode. With potassium bromide after heating in an atmosphere of bromine, under an applied field the coloration moves toward the cathode. The coloured materials behave as $n$ - and $p$-type semiconductors respectively. Much of the work on the properties of alkali halides had been carried out by Pohl at Göttingen, and Dr. Mitchell emphasized the importance of such work on relatively simple lattices in gaining an understanding of the behaviour of more complex semiconductors. 